Revista Eletrônica de Direito Processual - REDP.

Rio de Janeiro. Ano 13. Volume 20. Número 1. Janeiro a Abril de 2019

Periódico Quadrimestral da Pós-Graduação Stricto Sensu em Direito Processual da UERJ

Patrono: José Carlos Barbosa Moreira (in mem.). ISSN 1982-7636. pp. 407-441

www.redp.uerj.br

\title{
ARGUMENTAÇÃO, FATOS E VERDADE NO PROCESSO PENAL EM ESTADOS CONSTITUCIONAIS ${ }^{1}$
}

\section{ARGUMENTATION, FACTS AND TRUTH IN THE CRIMINAL PROCESS IN CONSTITUTIONAL STATES}

\begin{abstract}
Paulo Alves Santos
Mestrando em Direito, Estado e Constituição pela Universidade de Brasília - UnB. Especialista em Argumentação Jurídica pela Universidade de Alicante/Espanha. Membro do Grupo de Pesquisa em Retórica, Argumentação Jurídica e Juridicidades da Universidade de Brasília - UnB. Analista Judiciário no Superior Tribunal de Justiça - STJ. E-mail: pauloas22@hotmail.com
\end{abstract}

Cláudia Rosane Roesler Doutora em Direito pela Universidade de São Paulo - USP. Professora da Universidade de Brasília - UnB. Coordenadora do Grupo de Pesquisa em Retórica, Argumentação Jurídica e Juridicidades da Universidade de Brasília - UnB. E-mail: croesler@unb.br

RESUMO: A constitucionalização dos ordenamentos jurídicos, fenômeno que pretendeu tornar possível o controle público sobre o exercício do poder político, impôs uma transformação na forma como são justificados os atos decisórios estatais, especialmente os de caráter judicial. Esta justificação constitucionalizada das decisões é exigível também nos aspectos fático-probatórios do raciocínio judicial, o que impõe que sejam repensadas as relações entre argumentação, exame dos fatos e busca da verdade no processo, sobretudo no processo penal, no qual questões fáticas assumem maior densidade. Com o

\footnotetext{
${ }^{1}$ Artigo recebido em 29/08/2018 e aprovado em 04/04/2019.
} 
Revista Eletrônica de Direito Processual - REDP.

Rio de Janeiro. Ano 13. Volume 20. Número 1. Janeiro a Abril de 2019

Periódico Quadrimestral da Pós-Graduação Stricto Sensu em Direito Processual da UERJ

Patrono: José Carlos Barbosa Moreira (in mem.). ISSN 1982-7636. pp. 407-441

www.redp.uerj.br

auxílio da teoria standard da argumentação jurídica, o artigo propõe caminhos para a interlocução entre estes elementos contingentes.

PALAVRAS-CHAVE: Argumentação em matéria de fatos; processo penal; raciocínio judicial; decisões judiciais; verdade processual.

ABSTRACT: The constitutionalisation of legal systems, a phenomenon that sought to make public control over the exercise of political power possible, required a transformation in the way in which state decision-making acts, especially those of a judicial nature, are justified. This constitutional justification of decisions is also required in the factualevidential aspects of judicial reasoning, which requires that the relations between argumentation, examination of facts and search for truth in the process, especially in criminal proceedings, in which factual issues assume greater density. With the help of the standard theory of legal argumentation, the article proposes ways for the interlocution between these contingent elements.

KEYWORDS: Argumentation on facts; criminal proceedings; judicial reasoning; judicial decisions; procedural truth.

\section{Introdução}

Este artigo propõe uma discussão acerca de como se pode compatibilizar a prática do raciocínio em matéria de fatos desenvolvido nas decisões proferidas nos processos penais com as exigências do constitucionalismo contemporâneo. ${ }^{2}$

A fim de alcançar o objetivo proposto, a primeira parte deste trabalho será dedicada a compreender as relações estabelecidas entre o direito e a argumentação nos Estados constitucionais, bem como a forma em que estas relações foram apreendidas pela teoria standard da argumentação jurídica. Nesse ponto, serão destacadas as principais

\footnotetext{
2 Com o termo constitucionalismo denominam-se duas coisas distintas: a) o fenômeno da constitucionalização do direito depois da II Guerra Mundial, com a proliferação de constituições rígidas repletas de direitos fundamentais e princípios; b) a teorização desse fenômeno (Atienza, 2013, p. 29). Ao longo do texto, a expressão refere-se usualmente ao primeiro significado, embora este segundo aspecto esteja sempre vinculado àquele primeiro de algum modo.
} 
Revista Eletrônica de Direito Processual - REDP.

Rio de Janeiro. Ano 13. Volume 20. Número 1. Janeiro a Abril de 2019

Periódico Quadrimestral da Pós-Graduação Stricto Sensu em Direito Processual da UERJ

Patrono: José Carlos Barbosa Moreira (in mem.). ISSN 1982-7636. pp. 407-441

www.redp.uerj.br

caraterísticas desta concepção do direito, ressaltando-se em que medida a abordagem do direito como argumentação se difere de outras perspectivas jusfilosóficas e de que modo a atividade jurisdicional é compreendida pelos argumentativistas.

Em seguida, a análise se direcionará às relações existentes entre direito, argumentação e verdade no processo penal, com o objetivo de oferecer um substrato teórico capaz de orientar a transposição, para o campo jurídico, de premissas epistemológicas que possam ser úteis aos juristas na resolução de problemas relacionados à reconstrução de fatos pretéritos por intermédio da argumentação. Nessa etapa, será proposto o conceito de verdade-correspondência (cognocistivismo) como premissa adequada para sustentar a existência e o desenvolvimento de processos judiciais penais, examinando-se os deveres e as dificuldades que a adoção desta perspectiva impõe aos juízes no desenvolvimento de uma justificação fático-probatória.

Ao final, reafirmando o pressuposto fundamental da teoria standard da argumentação jurídica no sentido de que é possível justificar racionalmente as decisões judiciais, inclusive em seus elementos de raciocínio probatório, são traçadas as linhas gerais para a construção de um processo penal em que a dimensão argumentativa do raciocínio fáticoprobatório seja prestigiada. Esta pretensão está em harmonia com a exigência constitucional de fundamentação integral dos provimentos jurisdicionais e demanda uma necessária compatibilização entre a pretensão epistemológica básica que norteia o processo penal e a existência de outros objetivos e valores jurídicos especificamente incidentes neste campo do direito.

\section{A teoria standart da argumentação jurídica e o problema da argumentação}

\section{jurídica nos Estados constitucionais}

A percepção de que o direito, especialmente nos Estados constitucionais da atualidade, qualifica-se como uma prática essencialmente argumentativa é intuitiva. De fato, as representações mais comuns da atividade jurídica envolvem a disputa de pontos de vista por litigantes em juízo, as negociações para formulação de contratos, a redação de atos decisórios que tentam convencer-nos de seu acerto e etc. A argumentação constitui um traço tão decisivo e característico da prática do direito que já se propôs ser possível a 
Revista Eletrônica de Direito Processual - REDP.

Rio de Janeiro. Ano 13. Volume 20. Número 1. Janeiro a Abril de 2019

Periódico Quadrimestral da Pós-Graduação Stricto Sensu em Direito Processual da UERJ

Patrono: José Carlos Barbosa Moreira (in mem.). ISSN 1982-7636. pp. 407-441

www.redp.uerj.br

construção de uma teoria geral da argumentação a partir de uma generalização da prática jurídica (logic is generalized jurisprudence). ${ }^{3}$

O papel de destaque que a argumentação possui no direito passou a ostentar particular notoriedade a partir da segunda metade do século XX, o que se deve, entre outras razões, ao abandono da tradição e da autoridade como fontes legitimadoras do exercício do poder. Esta função passou a ser exercida pela democracia deliberativa, a qual não se identifica simples e imediatamente com a vontade da maioria, mas exige que as ações e decisões públicas sejam submetidas a um processo de discussão racional. De outra parte, o fenômeno da constitucionalização, com destaque para a técnica de redação dos textos constitucionais, os quais veiculam, em grande parte, princípios jurídicos abstratos e valorativos, provocou um crescimento quantitativo e qualitativo da exigência de fundamentação, ou seja, de argumentação, nas deliberações dos órgãos públicos encarregados da criação e aplicação destas normas jurídicas. ${ }^{4}$

Estas mudanças produzidas nos sistemas jurídicos contemporâneos, com destacada influência sobre a atividade jurisdicional, aproximaram a argumentação de um aspecto central do direito: a decidibilidade. ${ }^{5}$ Aplicar o direito, nas sociedades que passaram a compreender o tratamento não arbitrário e a fundamentação dos atos judiciais como direitos humanos e fundamentais ${ }^{6}$, consiste não apenas em decidir questões controversas e colocar fim aos litígios, mas, principalmente, em demonstrar argumentativamente a correção destas decisões e, ainda mais, o porquê de a decisão aplicada ser preferível entre outras soluções possíveis.

Como consequência, também a filosofia do direito precisou se redirecionar para as perguntas cujas respostas tornaram-se mais necessárias aos juristas, questões que migraram

\footnotetext{
${ }^{3}$ TOULMIN, Stephen. The uses of argument. Cambridge: Cambridge University Press, 1958, passim.

${ }^{4}$ ATIENZA, 2013, p. 21.

${ }^{5}$ FERRAZ JUNIOR, Tercio Sampaio. Introdução ao Estudo do direito: técnica, decisão, dominação. $5^{\text {a } e d . ~}$ São Paulo: Atlas, 2007, p. 624ss.

${ }^{6}$ A Corte Americana de Direitos Humanos assentou que o dever de fundamentação das decisões judiciais é uma das "devidas garantias" contidas no art. $8^{\circ}$ da Convenção Americana de Direitos Humanos - Garantias Judiciais -, a qual exige que sejam demonstrados "quais foram os fatos, motivos e normas em que se baseou a autoridade para tomar sua decisão" (García Ibarra e outros vs. Equador, 2015). De igual modo, a Corte Europeia de Direitos Humanos compreende que o direito a um julgamento justo (fair trial), decorrente do art. $6^{\circ}$ da Convenção Europeia em Diretos Humanos, impõe que "as decisões dos juízes e tribunais devem indicar de maneira suficiente os motivos em que se fundam" (H. vs. Bélgica, 1987). Também no âmbito da Corte Africana de Direitos Humanos e dos Povos está estabelecida a necessidade de que a fundamentação das decisões judiciais, especialmente as condenatórias, possua fundamentação substancial, o que decorre do art. $7^{\circ}$ da Carta Africana de Direitos Humanos (Alex Thomas vs. Tanzânia, 2013).
} 
Revista Eletrônica de Direito Processual - REDP.

Rio de Janeiro. Ano 13. Volume 20. Número 1. Janeiro a Abril de 2019

Periódico Quadrimestral da Pós-Graduação Stricto Sensu em Direito Processual da UERJ

Patrono: José Carlos Barbosa Moreira (in mem.). ISSN 1982-7636. pp. 407-441

www.redp.uerj.br

de um nível predominantemente teórico, com indagações acerca da natureza do direito e da estrutura do ordenamento jurídico, para um nível mais prático, no qual se destacam perguntas acerca de como decidir, como apresentar bons argumentos capazes de influenciar as decisões, como analisar e avaliar argumentos contrários e favoráveis, como escolher entre argumentos reciprocamente excludentes e etc. Neste novo contexto, as concepções do direito desenvolvidas ao longo do século XX mostraram sua superveniente incapacidade de explicar suficientemente o fenômeno jurídico.

De fato, em uma concepção de direito espera-se que estejam articuladas, em grau razoavelmente consistente, as respostas a uma série de questões básicas que se apresentam a todos práticos e teóricos deste campo, tais como o limite entre o direito e o não-direito, as relações entre direito, poder e moral, os objetivos e valores que podem (ou não podem) ser alcançados através da prática jurídica e como se entendem as operações de produção, interpretação e aplicação do Direito. O século XX foi especialmente fecundo no desenvolvimento de concepções do direito, com o afloramento de diversas correntes que examinaram o direito por variados ângulos, mas que também deixaram aspectos inexplorados, entre eles a dimensão argumentativa da prática jurídica.

O positivismo normativista é provavelmente a concepção do direito mais difundida no século passado. Com ela, a partir de uma rígida separação conceitual entre direito e moral, o campo jurídico adquiriu autonomia científica, fundada na convicção de que a definição do que é direito não depende de critérios ou argumentos morais. Este fundamento possibilitou a proposta de se caracterizar o direito como um conjunto normativo hierarquizado e centrado na ideia de validade, em que os níveis normativos superiores conferem autoridade às normas de níveis inferiores, sendo perfeitamente possível identificar estas normas por suas fontes sociais. ${ }^{7}$

Contudo, a versão forte do positivismo normativista não apresentou mecanismos para explicar e explorar as normas-princípios, cuja operacionabilidade exige mais do que os conceitos de validade e derivação hierárquica podem oferecer, um limite teórico significativo e bastante explorado na crítica de Ronald Dworkin ${ }^{8}$. Esta mesma limitação não permitiu que o papel dos juízes fosse completamente explorado pelos positivistas,

\footnotetext{
${ }^{7}$ MORESO, José Juan. El positivismo jurídico y la aplicación del Derecho. DOXA, no 27, p. 45-62, 2004, passim.

${ }^{8}$ DWORKIN, Ronald. Taking Rights Seriously. Cambridge: Harvard, University Press, 1977.
} 
Revista Eletrônica de Direito Processual - REDP.

Rio de Janeiro. Ano 13. Volume 20. Número 1. Janeiro a Abril de 2019

Periódico Quadrimestral da Pós-Graduação Stricto Sensu em Direito Processual da UERJ

Patrono: José Carlos Barbosa Moreira (in mem.). ISSN 1982-7636. pp. 407-441

www.redp.uerj.br

havendo uma conformação cética de que, diante de situações decisórias mais complexas, desemborcava-se em uma discricionariedade judicial próxima à arbitrariedade. Acrescentese, ainda, que o fenômeno da constitucionalização, ao incorporar ao direito um vasto catálogo de valores fundamentais sob a forma de princípios que devem ser seriamente levados em consideração nos processos decisórios, fez com que uma simples defesa da autonomia entre o direito e a moral se tornasse insuficiente para dar conta dos problemas jurídicos nos Estados constitucionais. ${ }^{9}$

De outra parte, uma concepção do direito como o jusnaturalismo racionalista, também razoavelmente difundido no século $\mathrm{XX}$, deslocaria o foco de atenção das normas provenientes de uma fonte com autoridade social para a identificação das razões que justificam as ações e escolhas humanas sem apelo a nenhuma autoridade que não a da própria razão prática. ${ }^{10}$ Desse modo, por intermédio do raciocínio crítico, em uma atividade predominantemente investigativa, seria possível descobrir os fundamentos últimos do direito e, portanto, distinguir o direito e o não-direito de acordo com estes parâmetros, competindo ao jurista apenas a declaração formal e exteriorização de uma realidade já previamente inscrita na natureza humana.

Uma concepção do direito assim delineada, embora introduza um raciocínio muitas vezes útil do ponto de vista prático, abrindo espaço para uma crítica à lei positivada e ao sistema normativo estatal, minimiza as especificidades do raciocínio jurídico na sua relação com a razão prática geral, negligenciando especialmente o papel que a autoridade e a dinâmica política desempenham no direito. Além disso, a amplitude e a generalidade atribuídas à racionalidade humana, pretensamente capaz de definir direitos por si mesma, tende a negar o caráter de fenômeno social e histórico do direito, apresentando-lhe com uma falsa imagem mistificada e idealizada. ${ }^{11}$

Outra concepção desenvolvida em meados do século passado com bastante ressonância entre acadêmicos e práticos é o realismo jurídico, seja na versão estadunidense (Holmes, Pound, Frank...) seja na versão escandinava (Ross, Hägerström, Olivercrona...). Em termos gerais, uma vez que há vários matizes entre os realistas, esta concepção assume o direito como uma prática indeterminada, vinculada essencialmente ao que fazem os

\footnotetext{
${ }^{9}$ RÓDENAS CALATAYUD, Ángeles. ¿Qué queda del positivismo jurídico? DOXA, n 26, p. 417-448, 2003.

${ }^{10}$ GEORGE, Robert Peter. Natural Law. The American Journal of Jurisprudence, ${ }^{\circ}$ 52, pp. 55-75, 2007.

${ }^{11}$ ATIENZA, Manuel. O direito como argumentação. Lisboa: Escolar Editora, 2014, p. 70.
} 
Revista Eletrônica de Direito Processual - REDP.

Rio de Janeiro. Ano 13. Volume 20. Número 1. Janeiro a Abril de 2019

Periódico Quadrimestral da Pós-Graduação Stricto Sensu em Direito Processual da UERJ

Patrono: José Carlos Barbosa Moreira (in mem.). ISSN 1982-7636. pp. 407-441

www.redp.uerj.br

juízes e demais funcionários que o aplicam, e cuja função é meramente instrumental em relação a determinados objetivos externos ao direito. Desse modo, em uma crítica direta à caricatura formalista do juiz como simples servente de normas cujo conteúdo foi previamente determinado pelo legislador, os realistas assinalam a centralidade do papel criativo dos juízes no desenvolvimento real do direito. Contudo, esta centralidade da atuação judicial assume contornos quase absolutos, ao ponto de a legislação ou o precedente judicial serem percebidos como, no máximo, um ponto de partida com relevância muito limitada para a solução de problemas jurídicos ${ }^{12}$.

Como se vê, os realistas ofereceram uma inegável contribuição à filosofia do direito ao assinalarem a necessidade de uma aproximação mais detida acerca da atividade dos juízes, que, sobretudo nos Estados constitucionais contemporâneos, não pode ser entendida em termos puramente lógicos-formais, como simples subsunção de normas a casos concretos. Contudo, embora uma investigação acerca do funcionamento real do aparato jurisdicional seja útil para o desenvolvimento de uma teoria do direito, a redução do direito a esse único aspecto incorre em duas consequências indesejáveis.

Em primeiro lugar, o realismo assume uma falácia naturalista, segundo a qual o direito (ou qualquer outra prática social) "é o que é”, como se se tratasse de um objeto natural, o que eliminaria a responsabilidade política dos agentes que intervêm e atuam na sua construção. Em segundo lugar, a adoção de um ceticismo quanto à normatividade das regras e princípios, inclusive constitucionais, termina por admitir como válido qualquer direito efetivamente praticado, ainda que absolutamente contrário ao ordenamento jurídico estabelecido pela comunidade política. ${ }^{13}$

Embora várias outras concepções de direito presentes no século XX pudessem ser aqui elencadas, contendo todas elas seus méritos e limites, já é possível observar, a partir dos exemplos ilustrados, os principais elementos que justificaram o desenvolvimento de uma concepção argumentativa do direito nos termos pensados pela teoria standard. Entre as necessidades fundantes desta perspectiva, ocupa lugar de destaque a percepção de que, para uma completa compreensão da constitucionalização e de sua influência sobre toda a

\footnotetext{
${ }^{12}$ ROSS, Alf. Sobre el derecho y la justicia. 2. ed. Buenos Aires: Eudeba, 1997, passim.

${ }^{13}$ FERRAJOLI, Luigi. El futuro de la filosofía del derecho. DOXA, no 39, 2016, p. 261.
} 
Revista Eletrônica de Direito Processual - REDP.

Rio de Janeiro. Ano 13. Volume 20. Número 1. Janeiro a Abril de 2019

Periódico Quadrimestral da Pós-Graduação Stricto Sensu em Direito Processual da UERJ

Patrono: José Carlos Barbosa Moreira (in mem.). ISSN 1982-7636. pp. 407-441

www.redp.uerj.br

prática jurídica, passou a ser necessária uma concepção de direito capaz de conciliar razoavelmente os campos do direito e da moral.

Do ponto de vista da teoria standard, a chave para a harmonização destes dois campos da razão prática está na ideia de que o direito é, fundamentalmente, uma prática social cujo significado é dado por determinados fins e valores, sendo a principal atribuição dos juristas integrar, em um todo coerente, a dimensão autoritativa do direito, cuja importância é inafastável, com a ordem de valores expressada nos princípios que dirigem esta prática. Uma configuração assim delineada pretende reconhecer os componentes políticos e morais que também integram a prática jurídica, porém se esforça por evitar uma indevida confusão entre direito, moral e política. ${ }^{14}$ A partir desta premissa geral, desenvolve-se uma relação de relativa independência entre o direito e a moral ${ }^{15}$, na qual, nos termos formulados por Atienza e Ruiz Manero ${ }^{16}$, o direito opera como um sistema justificativo estruturado em dois níveis distintos.

$\mathrm{O}$ primeiro nível de justificação está integrado pelas regras jurídicas ${ }^{17}$, as quais veiculam razões peremptórias (protegidas ou autoritativas) capazes de justificar uma decisão jurídica por si mesmas, na maior parte dos casos e sem necessidade de que se instaure uma ampla discussão sobre os valores e princípios que lhes possam ser favoráveis ou contrários. Todavia, estas razões peremptórias funcionam dentro de certos limites, pois: a) é possível que as regras possuam problemas de indeterminação em sua formulação; b) é possível que surjam casos novos para os quais não há uma regra formulada; e c) é possível que a aplicação das regras resulte em uma solução inaceitável à luz dos princípios do sistema. Quando alguma destas últimas situações se configura, a discussão ingressa em um nível mais complexo de justificação. Neste segundo nível justificativo, encontram-se os

\footnotetext{
${ }^{14}$ ATIENZA, 2013, p. 30

${ }^{15}$ É necessário registrar que os autores da teoria standard da argumentação jurídica, embora sejam unânimes em admitir uma necessária relação entre o direito e a moral, apresentam diferentes visões acerca de como estas relações se configuram. Um bom exemplo desta polêmica entre os argumentativistas é a tese do caso especial formulada por Alexy (2007), da qual Atienza (2003) discorda expressamente.

${ }^{16}$ ATIENZA, Manuel. RUIZ MANERO, Juan. Las piezas del Derecho: Teoría de los enunciados jurídicos. Barcelona: Ariel, 1996.

17 Os autores definem a diferença entre regras (em sentido estrito) e princípios assinalando que “...os princípios configuram o caso de forma aberta, enquanto as regras fazem-no de forma fechada. Com isso queremos dizer que, enquanto nas regras as propriedades que conformam o caso constituem um conjunto finito e fechado, nos princípios não se pode formular uma lista fechada das mesmas: não se trata somente de que as propriedades que constituam as condições de aplicação tenham uma periferia maior ou menor de vagueza, mas que estas condições não se encontram sequer genericamente determinadas" (Atienza et Ruiz Manero, 1996, p. 9)
} 
Revista Eletrônica de Direito Processual - REDP.

Rio de Janeiro. Ano 13. Volume 20. Número 1. Janeiro a Abril de 2019

Periódico Quadrimestral da Pós-Graduação Stricto Sensu em Direito Processual da UERJ

Patrono: José Carlos Barbosa Moreira (in mem.). ISSN 1982-7636. pp. 407-441

www.redp.uerj.br

princípios jurídicos substanciais e institucionais, os quais devem ser utilizados e, em caso de multiplicidade de princípios aplicáveis, sopesados entre si, a fim de que se alcance uma regra capaz de justificar a decisão no caso concreto, em uma operação de concretização destes mesmos princípios.

Nesta forma de funcionamento do raciocínio jurídico, resulta crucial a capacidade que o jurista deve possuir para movimentar-se entre os distintos níveis justificativos, o que não se realiza de forma abstrata, como em um catálogo preestabelecido, mas por meio da análise argumentativa a partir do caso concreto. Por essa razão, alguns exemplos podem ajudar a elucidar a forma como ocorre esse movimento.

Consideremos a moldura fática do caso Riggs vs. Palmer ${ }^{18}$, no qual a Corte de Apelações de Nova Iorque impediu que um condenado pelo homicídio do testador pudesse receber o patrimônio que lhe foi deixado pela sua vítima em testamento, afastando a aplicação regular das regras de sucessão testamentária. Neste caso, a insuficiência de aplicação das regras jurídicas revela-se em razão da inaceitável conclusão que seria gerada pela concessão da herança testamentária ao assassino do testador. Isto permitiria que Elmer Palmer alcançasse exatamente o que pretendia ao perpetrar o ato criminoso e validaria juridicamente a estratégia por ele empregada, em detrimento de valores substanciais do sistema jurídico, como a vida e a liberdade patrimonial (pois o assassinato teria sido motivado também por um possível desejo do testador em modificar suas disposições de última vontade em favor de uma terceira pessoa).

Uma solução juridicamente fundamentada para este caso necessitaria ingressar no campo dos princípios jurídicos. Neste nível justificativo mais complexo, sopesando-se, de uma parte, o princípio de que o sistema jurídico não pode ser utilizado para que o autor do ilícito dele se beneficie e, de outra parte, o princípio da legalidade, buscar-se-ia uma regra de justificação universalizável e aplicável ao caso concreto. No caso, como no campo do direito sucessório, portanto jurisdição civil, o princípio da legalidade não ocupa lugar de destaque, ao passo que a liberdade patrimonial, completamente tolhida com a morte do testador, é um pilar fundamental, a confrontação entre os princípios conduziria a uma regra de caráter justificativo e universalizável: todo aquele que comete assassinato contra o testador não pode beneficiar-se do testamento.

18 Decisão do caso disponível em http://www.courts.state.ny.us/reporter/archives/riggs_palmer.htm. Consultado em 07/2018. Este exemplo é também utilizado em Dworkin, 1977. 
Revista Eletrônica de Direito Processual - REDP.

Rio de Janeiro. Ano 13. Volume 20. Número 1. Janeiro a Abril de 2019

Periódico Quadrimestral da Pós-Graduação Stricto Sensu em Direito Processual da UERJ

Patrono: José Carlos Barbosa Moreira (in mem.). ISSN 1982-7636. pp. 407-441

www.redp.uerj.br

Em outro exemplo, consideremos a moldura fática do habeas corpus de Ruan Ramos do Nascimento no Superior Tribunal de Justiça brasileiro (HC n. 428.511/RJ) ${ }^{19}$, no qual se declarou a nulidade de audiência penal realizada na fase de instrução do processo penal sem a observância da regra de registro audiovisual dos atos processuais. Nesta situação, havia uma regra jurídica expressa no sentido de que, nos processos penais, o registro dos depoimentos do investigado, indiciado, ofendido e testemunhas deve ser feito pelos meios ou recursos de gravação audiovisual. Todavia, o juízo de primeira instância responsável pela condução do processo penal no qual Ruan Ramos era acusado decidiu afastar a aplicação da mencionada regra, utilizando o argumento, entre outros, de que o sistema de gravação audiovisual interferia na celeridade da tramitação processual.

A decisão do juízo singular foi reformada na instância superior, entre outros fundamentos, pelo fato de que o princípio jurídico invocado pelo Magistrado (celeridade processual) contrastava com os princípios jurídicos que conduziram à formulação da regra cuja aplicação foi negada, especialmente os princípios da ampla defesa e do contraditório. Isto porque, segundo avaliou a Corte Superior, a introdução da gravação audiovisual pretende conferir maior fidelidade ao registro das provas obtidas em audiência, permitindo que a defesa as utilize mais plenamente em sua argumentação. Portanto, nesta segunda hipótese, a passagem ao nível valorativo da justificação jurídica, ao possibilitar o sopesamento dos valores em jogo em cada uma das soluções possíveis, resultou na confirmação daquela regra posta pelo legislador.

Todavia, é certo que nem todas as discussões jurídicas irão exigir um aprofundamento da justificação acerca dos fundamentos principiológicos das regras aplicadas. Um número relativamente restrito de discussões alcança esta densidade justificativa, ao passo que muitas controvérsias jurídicas estarão centradas em problemas de natureza distinta. Nesse aspecto, podemos imaginar as dezenas de ações de cobrança que ingressam nos sistemas judiciais todos os dias. Não é comum que se discuta neste tipo de processo judicial a própria correção valorativa das regras que regulam os contratos ou os fundamentos últimos deste instituto, mas sim a efetiva existência de um acordo de vontades capaz de originar a dívida, a eventual existência de vícios contratuais (estado de

\footnotetext{
${ }^{19}$ Decisão do caso disponível em: https://ww2.stj.jus.br/processo/revista/documento/mediado/?componente=ITA\&sequencial=1701652\&num_r egistro $=201703214023 \&$ data $=20180425 \&$ formato $=P D F$. Consultado em 07/2018.
} 
Revista Eletrônica de Direito Processual - REDP.

Rio de Janeiro. Ano 13. Volume 20. Número 1. Janeiro a Abril de 2019

Periódico Quadrimestral da Pós-Graduação Stricto Sensu em Direito Processual da UERJ

Patrono: José Carlos Barbosa Moreira (in mem.). ISSN 1982-7636. pp. 407-441

www.redp.uerj.br

perigo, coação, incapacidade...), a submissão do contrato entabulado à alguma legislação especial ou a forma como devem ser interpretadas as cláusulas de cálculo da dívida. Em verdade, em casos assim, as soluções adotadas também exigem fundamentação consistente, a qual, porém, permanece no nível justificativo de aplicação das regras.

Em todos os casos, o que se percebe é a centralidade que a argumentação assume para a determinação dos rumos da decisão no caso concreto. De fato, é a explicitação das razões de decidir e a possibilidade de controle racional da argumentação utilizada que inibe, por um lado, o apego a um formalismo institucional irracional e, por outro lado, o subjetivismo judicial desvinculado da existência institucional do direito. Além disso, há uma nítida separação entre o exercício do poder e o atributo da racionalidade, uma vez que decisões mal fundamentadas, independentemente do maior ou menor grau de autoridade que possuam, serão sempre decisões ruins, as quais podem inclusive não mais estarem sujeitas a um controle institucional, mas cuja argumentação explicitada sempre poderá ser objeto de controle de racionalidade interno e externo ao direito.

Este controle racional é ressaltado pela assimilação, na teoria standard da argumentação jurídica, da diferenciação entre o contexto da descoberta e o contexto da justificação. ${ }^{20} \mathrm{Na}$ filosofia da ciência, o primeiro contexto se refere aos processos, conscientes ou não, que conduzem ao descobrimento de uma nova fórmula ou teoria, entre os quais se podem encontrar fontes de inspiração bastante diversos. O contexto da justificação, por seu turno, diz respeito ao processo de validação da descoberta, da demonstração da correção do conhecimento encontrado através do método científico. No clássico exemplo da teoria da gravidade, a inspiração da maçã que caiu sobre Newton pode tê-lo feito compreender algo sobre o funcionamento das forças físicas, mas certamente este acontecimento, próprio do contexto da descoberta, não seria capaz de sustentar a sua teoria no contexto da justificação.

No campo da argumentação jurídica, o contexto da descoberta reúne os aspectos psicológicos, ideológicos e idiossincráticos de quem argumenta, ao passo que no contexto da justificação estão as razões explicitamente apresentadas para motivar um determinado posicionamento. Em virtude da independência entre estes dois contextos, a correção de

\footnotetext{
${ }^{20}$ AGUILÓ REGLA, Josep. De nuevo sobre independencia e imparcialidad de los jueces y argumentación jurídica. Jueces para la democracia, $n^{\circ} 46,2003$, p. 47-48.
} 
Revista Eletrônica de Direito Processual - REDP.

Rio de Janeiro. Ano 13. Volume 20. Número 1. Janeiro a Abril de 2019

Periódico Quadrimestral da Pós-Graduação Stricto Sensu em Direito Processual da UERJ

Patrono: José Carlos Barbosa Moreira (in mem.). ISSN 1982-7636. pp. 407-441

www.redp.uerj.br

uma decisão pode e deve ser avaliada a partir dos argumentos apresentados nas razões expostas para justificá-la, cuja compreensão não possui nenhuma correlação necessária com aqueles fatores que conduziram inicialmente ao contexto da descoberta, os quais nem sempre são conhecidos ou explicáveis racionalmente.

Há, assim, uma limitação sobre o que interessa à teoria standard acerca dos juízes. $\mathrm{O}$ interesse dos argumentativistas se volta para aquilo que os juízes fazem e devem fazer, como argumentam em suas decisões e como podem fazê-lo da melhor forma possível, e não sobre aquilo que os juízes são. Efetivamente, são nas razões explicitadas na decisão judicial, e não na subjetividade do juiz, que a tensão entre as dimensões autoritativa e valorativa do direito aparecerão de forma mais nítida e compreensível, razão pela qual não é estranho que os autores da teoria standard tenham inicialmente envidado seus maiores esforços para o desenvolvimento de uma teoria da argumentação justificativa amoldada às decisões judiciais. Apesar da pretensão de que outros espaços da argumentação no direito sejam explorados (como a argumentação dos advogados ou do legislador), é no campo da fundamentação das decisões dos juízes e similares que se encontram atualmente as maiores contribuições da teoria da argumentação jurídica.

Por certo, é determinante para a formulação de uma concepção argumentativa do direito a necessidade de desenvolver a temática do papel desempenhado pelos juízes nos Estados constitucionais. Das concepções de direito características do século XX inferemse diversas ilustrações insatisfatórias da atividade judicial: um juiz formalista para o qual o cumprimento das regras ditadas pela autoridade é suficiente, independentemente de seu conteúdo ou finalidade; ou um juiz positivista que, na ausência de um comando normativo expresso, pode decidir como lhe for conveniente; ou um juiz naturalista que, para alcançar um ideal de justiça, pode ignorar completamente a ordem jurídica vigente; ou, ainda, um juiz realista, que se encontra no centro do direito e "decide como decide", devendo a teoria jurídica esforçar-se para tentar predizer suas decisões. Todas estas imagens compartilham dois traços em comum e intrinsecamente relacionadas: a pouca importância que possuiria eventual fundamentação da decisão destes juízes e a completa incompatibilidade entre estas formas de exercício do poder e as aspirações de tratamento não arbitrário assumidas nas constituições contemporâneas. ${ }^{21}$

\footnotetext{
${ }^{21}$ AGUILÓ REGLA, Josep. Sobre la constitución del Estado constitucional. DOXA, nº 24, 2001, p. 451.
} 
Revista Eletrônica de Direito Processual - REDP.

Rio de Janeiro. Ano 13. Volume 20. Número 1. Janeiro a Abril de 2019

Periódico Quadrimestral da Pós-Graduação Stricto Sensu em Direito Processual da UERJ

Patrono: José Carlos Barbosa Moreira (in mem.). ISSN 1982-7636. pp. 407-441

www.redp.uerj.br

Por tudo o que foi exposto, é razoável sustentar que o juiz de um estado constitucional deve adotar uma postura argumentativa frente ao direito. Esta posição argumentativa consiste justamente em reconhecê-lo como uma prática regida por regras e princípios, com inafastável caráter valorativo, na qual a função decisória deve estar suficientemente justificada com base no direito e nos fins e valores por ele perseguidos, com adequado distanciamento dos fatores subjetivos que influenciaram no contexto da descoberta e cujas razões se submetem ao escrutínio público institucional e não institucional. Tal postura, por certo, deve se estender à toda atividade jurisdicional, o que logicamente inclui a justificação das decisões em temas fático-probatórios.

A obrigação de dar razões para decisões, dessa forma, não se resumiria à simples indicação das premissas que compõem o silogismo judicial, normalmente identificadas como o pressuposto fático e pressuposto normativo da decisão, mas exigiria, fundamentalmente, a apresentação de um raciocínio capaz de justificar a construção dessas premissas. O que se afirma, portanto, é a necessidade de que o juiz justifique com clareza suas decisões, tanto interna quanto externamente. ${ }^{22}$

Se compreendermos a decisão judicial como um silogismo no qual são inseridas duas premissas (uma normativa e outra fática), resultando em um comando normativo que orienta a ação no caso concreto, uma justificação adequada deve cuidar de demonstrar que das premissas apontadas decorre logicamente o resultado proposto, o que satisfaz a exigência de justificação interna. Contudo, a justificação interna não é suficiente para suprir a exigência de fundamentação da decisão, pois a lógica somente trata de assegurar a correção do resultado do raciocínio dedutivo em função das premissas apresentadas, mas não se ocupa de avaliar a correção das premissas.

A justificação externa consiste, desse modo, em averiguar a qualidade das premissas do raciocínio judicial. No campo normativo, trata-se de verificar se há bons argumentos para que aceitemos que as normas estão sendo corretamente compreendidas e aplicadas pelo julgador. Do ponto de vista fático, está relacionada aos argumentos pelos quais se procura demonstrar que determinada reconstrução discursiva dos fatos é mais apropriada. Em ambos os campos, não se trata de uma tarefa simplesmente lógico-dedutiva, mas exige a incorporação de outras formas de raciocínio.

\footnotetext{
${ }^{22}$ ATIENZA, 2013, passim.
} 
Revista Eletrônica de Direito Processual - REDP.

Rio de Janeiro. Ano 13. Volume 20. Número 1. Janeiro a Abril de 2019

Periódico Quadrimestral da Pós-Graduação Stricto Sensu em Direito Processual da UERJ

Patrono: José Carlos Barbosa Moreira (in mem.). ISSN 1982-7636. pp. 407-441

www.redp.uerj.br

A exigência de fundamentação externa torna as decisões judiciais potencialmente mais complexas nos Estados constitucionais. De fato, assim como há controvérsias nas quais não se exige um juízo valorativo mais intenso, limitando-se a discussão ao nível justificativo das regras peremptórias, há também problemas cujas premissas normativa e/ou fática não suscitam maiores indagações. Todavia, quanto mais intensos forem os desacordos a respeito da correção das premissas, mais exigente e necessária se torna a justificação externa da decisão. Grandes controvérsias constitucionais, normalmente enfrentadas por Cortes Supremas, costumam demandar uma justificação mais detalhada das premissas normativas empregadas, as quais usualmente recorrem aos valores últimos da comunidade política. Por outro lado, controvérsias penais, na qual a vinculação a regras positivadas é mais intensa, tendem a demandar menor esforço para a justificação externa da premissa normativa, ao passo que normalmente necessitam ser bastante minuciosas na justificação externa da premissa fática.

Como já destacado, a teoria standard da argumentação jurídica foi mais profícua ao desenvolver de instrumentos analíticos e avaliativos no campo da argumentação para interpretação normativa. Contudo, considerando que os pressupostos da teoria standard são aplicáveis à toda a atividade jurisdicional, também a justificação externa de argumentos fático-probatórios demanda igual submissão a mecanismos racionais de análise e avaliação. Para que se alcance o almejado controle da arbitrariedade no exercício do poder, especificamente do poder jurisdicional, objetivo que é comum ao constitucionalismo e às teorias da argumentação jurídica, o exame dos raciocínios judiciais probatórios não pode ser deixado em segundo plano.

Portanto, não só é exigível que os juízes em Estados constitucionais sejam capazes de apresentar boas razões para que se aceitem como provados os fatos utilizados em suas decisões, mas é ainda mais importante que as teorias da argumentação sejam capazes de oferecer mecanismos para que estas razões fáticas sejam elaboradas, organizadas, compreendidas e, se necessário, criticamente contestadas. Uma concepção argumentativa do direito nos direciona ao desenvolvimento de técnicas argumentativas de raciocínio probatório, pois, na ausência destas, aquela permanece incompleta.

\section{Verdade e argumentação jurídica na atividade jurisdicional penal}


Revista Eletrônica de Direito Processual - REDP.

Rio de Janeiro. Ano 13. Volume 20. Número 1. Janeiro a Abril de 2019

Periódico Quadrimestral da Pós-Graduação Stricto Sensu em Direito Processual da UERJ

Patrono: José Carlos Barbosa Moreira (in mem.). ISSN 1982-7636. pp. 407-441

www.redp.uerj.br

A argumentação em matéria de fatos tem sido objeto de recente desenvolvimento no âmbito da chamada teoria standard da argumentação jurídica. Embora ainda não se possa igualar a produção acadêmica em torno da argumentação em matéria de fatos àquela voltada à argumentação para interpretação de normas jurídicas, constata-se uma diversidade de estudos nas últimas décadas capazes de auxiliar os práticos do direito acerca de como bem argumentar nos raciocínios probatórios judiciais, em especial no processo penal, onde problemas deste gênero assumem maior densidade.

O descompasso entre o desenvolvimento das teorias da argumentação no campo normativo e no campo fático pode ser explicado por diversos fatores, entre os quais se destacam a constante negativa de controle das conclusões fáticas pelos tribunais hierarquicamente mais elevados, o que faz com que os problemas probatórios não alcancem maior visibilidade, e a existência de sofismas comumente aceitos que minam ou, no limite, excluem - a necessidade de fundamentação judicial nos aspectos fáticos. ${ }^{23}$ Estes recursos materialmente inconsistentes, utilizados na prática jurídica como escudos para a falta de motivação judicial, são comumente expressos como derivações do "livre convencimento" do juiz ou de seu acesso privilegiado à "verdade real". ${ }^{24}$

De outra parte, a construção de uma prática jurídica que relega ao plano marginal a argumentação em matéria de fatos é também reflexo de ideias presentes no senso comum de que "os fatos são os fatos" e "contra fatos não há argumentos", afirmações que se fundam em uma confiança extremada na razão empírica subjetiva, almejando dispensar maiores justificações sobre o exame das provas. ${ }^{25}$ Esta mesma ideologia está expressa na máxima jurídica da mihi factum dabo tibi ius, que cristaliza uma dualidade entre o mundo dos fatos, externamente apresentados ao juiz pelos litigantes, e o mundo jurídico no qual se desenvolve a decisão.

$\mathrm{Na}$ experiência jurídica histórica, o enfrentamento da matéria fática foi desde o abandono à pura irracionalidade (ordálios) à adoção de um sistema de racionalidade com pretensões absolutamente formalistas (prova taxada), de forma que o uso de alguma racionalidade argumentativa nos aspectos probatórios é, ao mesmo tempo, um avanço a ser

\footnotetext{
${ }^{23}$ ATIENZA, Manuel. Sobre la argumentación en materia de hechos: Comentario crítico a las tesis de Perfecto Andrés Ibáñez. DOXA, n 22, 1994, p. 82.

${ }^{24}$ BRUM, Nilo Bairros de. Requisitos retóricos da sentença penal condenatória. São Paulo: Editora RT, 1980 , passim.

${ }^{25}$ GASCÓN ABELLÁN, Marina. Los hechos en el derecho. Madrid: Marcial Pons Ediciones, 2010, p. 11.
} 
Revista Eletrônica de Direito Processual - REDP.

Rio de Janeiro. Ano 13. Volume 20. Número 1. Janeiro a Abril de 2019

Periódico Quadrimestral da Pós-Graduação Stricto Sensu em Direito Processual da UERJ

Patrono: José Carlos Barbosa Moreira (in mem.). ISSN 1982-7636. pp. 407-441

www.redp.uerj.br

comemorado nos Estados constitucionais e um objetivo desafiador a ser constantemente perseguido. ${ }^{26}$ Em meio a diversas descontinuidades, a tentativa de adoção da racionalidade argumentativa em matéria probatória, reconhecendo-se a reconstrução discursiva dos fatos como um problema inatingível pelo simples empirismo e que demanda uma sólida argumentação jurídica, avança sempre ameaçada em estruturas marcadas pelo narcisismo togado, que se comprazem com o hermetismo decisório e com sua áurea quase mística. ${ }^{27}$

Em especial na América Latina, percebe-se uma ampliação recente da discussão acerca da argumentação em matéria de fatos no campo penal, fenômeno contextualmente ligado à redemocratização dos países latinos e à necessidade que estas nações têm de repensar os seus sistemas processuais criminais, os quais foram construídos sob o influxo de ideologias autoritárias. ${ }^{28}$ A vinculação entre estes acontecimentos é relevante, pois a prática jurídica dos Estados constitucionais deve estar comprometida com uma forma de prestação da jurisdição legitimada argumentativamente, sobretudo quando se coloca em juízo a liberdade humana.

A pretensão constitucionalista de limitação ao exercício arbitrário do poder, sobretudo em sua intersecção com o exercício do poder punitivo no âmbito penal, não pode prescindir de uma adequada conformação entre a aplicação de penas e a justificação de sua imposição. Esta justificação, por seu turno, não se limita ao campo da interpretação das normas penais, mas também se estende à fundamentação das premissas fáticas, desempenhando estas últimas, com frequência, proeminência no raciocínio penal.

Não por acaso, os Estados constitucionais contemporâneos adotaram como marco normativo penal a presunção de não-culpabilidade ${ }^{29}$, atraindo para o próprio Estado toda a carga argumentativa necessária para a prolação de um juízo condenatório. Esta carga

\footnotetext{
${ }^{26}$ Ibidem, p. 12-16.

27 ANDRÉS IBÁÑEZ, Perfecto. Acerca de la motivación de los hechos en la sentencia penal. DOXA, $\mathrm{n}^{\circ} 12$, p. 257-299, 1992, passim.

${ }^{28}$ Cf. MAIER, Julio; STRUENSEE, Eberhard. Las Reformas Procesales Penales en América Latina. Buenos Aires: Ad-Hoc, 2000.

${ }^{29} \mathrm{O}$ termo presunção de não-culpabilidade, ao invés de presunção de inocência, é mais adequado para enunciar a ideia contida neste princípio jurídico-penal, uma vez que expressa melhor o estado de incerteza acerca da culpa, ou seja, que não há qualquer definição sobre se a pessoa é inocente ou culpada. Com efeito, ao absolver por ausência de provas, uma das implicações práticas mais evidentes deste princípio, o juiz não afirma inocência, mas afasta a culpa em sentido amplo, o que demonstra ser mais correto falar-se em nãoculpabilidade do que em inocência. Em harmonia com esse entendimento, a Constituição brasileira, ao explicitar o princípio, optou pela fórmula "ninguém será considerado culpado até o trânsito em julgado de sentença penal condenatória" ao invés de "toda pessoa será considerada inocente até o trânsito em julgado da sentença condenatória”. Assim, a terminologia adotada também se justifica por razões dogmáticas.
} 
Revista Eletrônica de Direito Processual - REDP.

Rio de Janeiro. Ano 13. Volume 20. Número 1. Janeiro a Abril de 2019

Periódico Quadrimestral da Pós-Graduação Stricto Sensu em Direito Processual da UERJ

Patrono: José Carlos Barbosa Moreira (in mem.). ISSN 1982-7636. pp. 407-441

www.redp.uerj.br

incide não apenas sobre o estado-acusador, a quem compete apresentar os elementos e argumentos probatórios para comprovar a culpa, mas também sobre o estado-juiz, o qual, convencendo-se da culpabilidade do acusado, precisa demonstrar discursiva e publicamente as razões de seu convencimento.

A motivação adotada pelo juiz acerca dos fatos em julgamento, nesta perspectiva constitucional, deve ser capaz de demonstrar que a atribuição da responsabilidade penal ao indivíduo condenado não é aleatória, motivada por interesses estranhos ao direito, desconectada da realidade de suas ações ou omissões, enfim, injusta. A fundamentação da premissa fática é uma das principais barreiras para se garantir que o exercício do poder punitivo se revestirá de juridicidade e legitimidade. Por essa razão, não pode a comunidade jurídica, em especial os juízes, descuidar do desenvolvimento de instrumentos capazes de aprimorar a justificação fática das decisões judiciais.

Em verdade, o juiz de um estado constitucional não pode firmar premissas fáticas e considerá-las provadas com base apenas em sua íntima e solipsista convicção, nem motivála de forma meramente formal. É preciso que se argumente e justifique adequadamente como os fatos foram trazidos para a sentença. Um juiz que não se faz entender não é um juiz democrático e, para que possamos entendê-lo, é necessário que sua sentença exponha os argumentos de prova que tenham influído em seu veredito e discorra de forma comprometida acerca dos aspectos que poderiam influenciar no resultado da valoração probatória. ${ }^{30}$

De outra parte, é certo que o esforço dos sistemas jurídicos em construir processos para a análise e exame de provas, em incorporar neste processo pontos de vista antagônicos (acusação e defesa) e em cercar de garantias a atividade decisória no que tange aos fatos através de institutos como a imparcialidade e o duplo grau de jurisdição demonstram o desejo de se alcançar a reconstrução mais correta e precisa dos fatos possível. Sem esta reconstrução fática o raciocínio jurídico seria deficiente, pois a forma como se pensa a efetivação do direito exige a identificação de um substrato fático que seja pertinente às normas em aplicação, ou dito de outro modo, justiça substancial exige verdade fática. ${ }^{31}$

\footnotetext{
${ }^{30}$ SCHÖNBOHM, Hosrt. Manual de Sentencias Penales: aspectos generales de estructura, argumentación y valoración probatoria. Lima: ARA Editores, 2014, p. 106/120.

${ }^{31}$ HACK, Susan. Of Truth, in Science and in Law. Brooklyn Law Review, v. 73:3, 2008. P. 986.
} 
Revista Eletrônica de Direito Processual - REDP.

Rio de Janeiro. Ano 13. Volume 20. Número 1. Janeiro a Abril de 2019

Periódico Quadrimestral da Pós-Graduação Stricto Sensu em Direito Processual da UERJ

Patrono: José Carlos Barbosa Moreira (in mem.). ISSN 1982-7636. pp. 407-441

www.redp.uerj.br

A correção da premissa fática não é, portanto, um objetivo em si mesmo nos processos judicias, mas propriamente uma condição necessária para que as decisões dos juízes sejam bem justificadas. Desse modo, considerando que nos Estados constitucionais a justificação adequada das decisões desenvolve um papel legitimador, a verdade fática argumentativamente demonstrada torna-se indispensável para que uma decisão judicial seja apropriada, legítima e justa. ${ }^{32}$

Esta legitimação justificativa é ainda mais necessária quando as conclusões fáticas conduzem a um juízo penal condenatório, nas quais o raciocínio judicial probatório deve ser suficientemente confiável para elidir a presunção de não-culpabilidade, marco jurídiconormativo adotado no direito penal dos Estados constitucionais. A motivação argumentativa dos fatos está carregada, nesse aspecto, de um intenso conteúdo políticogarantista, ${ }^{33}$ inclusive em vista do impacto extraprocessual decorrente da conversão de não-culpados em culpados, o que não pode ser admitido sem a exigência de verdade factual. Em verdade, a última barreira que separa o cidadão das sérias consequências penais e extrapenais de uma condenação pela prática de ato delitivo é a fundamentação da decisão judicial, na qual os argumentos fáticos são decisivos.

Neste modelo de motivação como garantia adotado nos Estados constitucionais, a atividade decisória em matéria de fatos se apresenta como um poder-saber. ${ }^{34} \mathrm{O}$ exercício do poder punitivo é legitimado em função da qualidade do que se sabe acerca dos fatos, motivo pelo qual o processo deve buscar explicitar, com a máxima acurácia e diligência possíveis dentro dos limites do direito, uma verdade racionalmente determinada em seu raciocínio probatório. Com efeito, o poder judicial torna-se mais legítimo quanto maior o saber que se demonstra acerca dos fatos que julga.

Todavia, o conceito de verdade não é unívoco. Há diversas correntes teóricas que se dedicaram ao estudo dos problemas que a verdade origina, cujas conclusões obtidas não são necessariamente excludentes, especialmente se aplicadas no contexto judicial, que de algum modo comporta abordagens provenientes de mais de uma delas.

\footnotetext{
32 TARUFFO, Michele. La prueba. Tradução de Laura Manríquez e Jordi Ferrer Beltrán. Madrid: Marcial Pons, 2008, p. 23.

${ }^{33}$ ANDRÉS IBÁÑEZ, 1992, p. 261.

${ }^{34}$ FERRAJOLI, Luigi. Principia iuris: teoría del derecho y de la democracia. Tradução de Perfecto Andrés Ibáñez, Carlos Bayón, Marina Gascón, Luis Prieto Sanchís y Alfonso Ruiz Miguel. Madrid: Trotta, 2011, P. 214.
} 
Revista Eletrônica de Direito Processual - REDP.

Rio de Janeiro. Ano 13. Volume 20. Número 1. Janeiro a Abril de 2019

Periódico Quadrimestral da Pós-Graduação Stricto Sensu em Direito Processual da UERJ

Patrono: José Carlos Barbosa Moreira (in mem.). ISSN 1982-7636. pp. 407-441

www.redp.uerj.br

Organizando as teorias sobre a verdade em analogia com os campos de estudo da linguagem, um primeiro grupo centra a discussão acerca da verdade considerando-a em sua relação com o mundo físico (teorias semânticas), um segundo grupo compreende como verdade a concordância entre elementos de um sistema (teorias sintáticas) e, por fim, um último grupo de teorias defende que a verdade pode ser identificada em razão de sua conveniência ou utilidade para a ação (teorias pragmáticas). ${ }^{35}$

De tradição aristotélica, a base de todas as teorias semânticas consiste na compreensão da verdade como uma relação entre um enunciado propositivo e uma realidade objetiva e independente - o mundo. Assim, uma proposição qualquer (como $A$ matou $B$ ) somente é verdadeira se o seu referente empírico no mundo real estiver em conformidade com esta proposição, ${ }^{36}$ sendo central a relação de adequação entre a linguagem e a realidade. ${ }^{37}$ Nesta formulação é possível identificar dois elementos básicos: um componente metafísico, consistente na crença de que existe um mundo real independente do sujeito, e um componente gnosiológico, referente à aceitação de que é possível ao sujeito conhecer este mundo objetivo. ${ }^{38}$

A crítica mais comum que se costuma dirigir a esta teoria da verdade contesta a sua trivialidade. Afirma-se que uma fórmula genérica, vaga e plurívoca como "correspondência com real" transmite uma mensagem tão vazia que poderia ser interpretada de muitas maneiras diversas, inclusive incompatíveis entre si. ${ }^{39}$ Contudo, é justamente esta debilidade de significado e abertura interpretativa que possibilitou que a ideia de verdade como correspondência se tornasse um topos ${ }^{40}$ tão difundido no campo jurídico-penal, oferecendo um lugar comum para sustentar as discussões acerca dos fatos. É uma perspectiva de correspondência que funciona não como um instrumental para a obtenção da verdade, mas como um ideal regulativo, ou seja, um ponto de referência

\footnotetext{
${ }^{35}$ GASCÓN ABELLÁN, 2010, p. 51.

${ }^{36}$ Com mesmo sentido, mas com outra formulação, Alchourrón et Bulygin (1991, p. 310) definem que "se uma oração é empírica deve haver um fato empírico que o faça verdadeiro". Há inda outras formulações que estão sinteticamente apresentadas em Tarski, 1999.

37 MARTÍNEZ-FREIRE, Pascual F. La teoría de la verdade de Alfred Tarski. Contrastes. Revista Internacional de Filosofía, mar. 2016, p. 100.

${ }^{38}$ GASCÓN ABELLÁN, op. cit., p. 51

${ }^{39}$ MELÉNDEZ, Raul. La noción de verdade como correspondência. Ideas y Valores, n. 120, p. 121-128, 2002, passim.

40 Como topoi nos referimos aos pontos de partida para construção de premissas nas discussões argumentativas em geral, inclusive no campo jurídico (Roesler, 2009).
} 
Revista Eletrônica de Direito Processual - REDP.

Rio de Janeiro. Ano 13. Volume 20. Número 1. Janeiro a Abril de 2019

Periódico Quadrimestral da Pós-Graduação Stricto Sensu em Direito Processual da UERJ

Patrono: José Carlos Barbosa Moreira (in mem.). ISSN 1982-7636. pp. 407-441

www.redp.uerj.br

teórico para se ter em consideração com o objetivo de orientar o empreendimento da busca pelo conhecimento. ${ }^{41}$

A concepção de verdade como correspondência é também destinatária de uma crítica cética que questiona a possibilidade de existência de uma realidade objetiva independente da subjetividade do sujeito cognoscente. O debate neste ponto, apesar de ser epistemologicamente interessante, não atrai os práticos do direito. A existência de uma realidade externa é indispensável para se justificar o desenvolvimento do processo judicial como mecanismo para conhecê-la, inexistindo qualquer controvérsia relevante sobre este pressuposto entre os juristas, os quais, caso resolvessem ingressar em discussão com este nível de abstração, iriam paralisar completamente o sistema jurídico ou incorreriam em uma contradição performativa em cada ato decisório.

Além disso, a ideia de que existe um mundo real independente de nossa subjetividade decorre, antes de tudo, de uma postura intuitiva ${ }^{42}$ ou psicológica ${ }^{43}$, no sentido de que este é um pressuposto tão arraigado em nossa maneira de pensar, de atuar, de comunicar, de construir nossas instituições e etc. que não seria possível imaginar um mundo em que esta tese fosse completamente rechaçada. Em última análise, a principal razão para que, no campo jurídico, se aceite que a realidade existe é porque a prática jurídica radicalmente necessita que ela exista. ${ }^{44}$

Outra crítica de caráter cético comumente articulada é dirigida contra o elemento gnosiológico da ideia de verdade como correspondência, apontando a impossibilidade humana de se chegar a um conhecimento efetivo dos fatos. Esta crítica parte de um dado incontestável, que é a natural impossibilidade de obter absoluto conhecimento sobre a realidade total de fatos pretéritos e irrepetíveis, porém alcança, nas versões mais radicais ${ }^{45}$,

\footnotetext{
${ }^{41}$ TARUFFO, 2008, p. 26.

${ }^{42}$ GASCÓN ABELLÁN, 2010, p. 59.

${ }^{43}$ GONZÁLEZ LAGIER, Daniel. Hechos y argumentos. Racionalidad epistemológica y prueba de los hechos en el proceso penal -I. Jueces para la democracia, $n^{\circ}$ 46, 2003, p. 22.

${ }^{44}$ GONZÁLEZ LAGIER (2003), fazendo menção a Hume e a Strawson, compara a conceito de realidade ao conceito de livre arbítrio. O argumento desenvolvido é de que, assim como não seria possível imaginar um sistema judicial caso a ideia de livre arbítrio fosse negada, não há como justificar a existência do processo judicial em caso de total negativa da existência da realidade.

${ }^{45}$ Um ceticismo radical quanto aos fatos pode ser observado na obra de Jerome Frank (1973), porém sua crítica está muito delimitada ao sistema jurídico estadunidense, uma vez que se baseia fundamentalmente no adversary system em vigor naquele contexto. Desse modo, GASCÓN ABELLÁN (2010, p. 37) assinala que há interpretação, a contrario sensu, de que Frank admite a possibilidade de cognição dos fatos por meio do processo judicial, mas que o adversary system seria um meio equivocado de obtê-la.
} 
Revista Eletrônica de Direito Processual - REDP.

Rio de Janeiro. Ano 13. Volume 20. Número 1. Janeiro a Abril de 2019

Periódico Quadrimestral da Pós-Graduação Stricto Sensu em Direito Processual da UERJ

Patrono: José Carlos Barbosa Moreira (in mem.). ISSN 1982-7636. pp. 407-441

www.redp.uerj.br

uma consequência exagerada, que é a afirmação da absoluta impossibilidade de qualquer conhecimento acerca destes fatos pretéritos.

Esta conclusão desproporcional é igualmente incompatível com os pressupostos de existência do processo judicial. Abandonar a tentativa de se conhecer com a maior fidelidade possível os fatos passados implicaria na impossibilidade de o sistema jurídico coibir coercitivamente infrações ao direito, pois não haveria forma de garantir a vinculação entre as condutas dos membros da sociedade e a aplicação da sanção, criando-se punitivo sistema verdadeiramente aleatório. ${ }^{46}$ É justamente para que isso não ocorra que o grau de incerteza presente na atividade de comprovação de fatos pretéritos é administrado por meio de regulações acerca de como se deve fazer, provar e contestar alegações sobre o passado no processo. ${ }^{47}$

Deve-se destacar, ainda, que a referida crítica incorre em uma falácia de composição, confundindo uma pequena parte das teorias da verdade como correspondência com o todo. Em verdade, somente um certo tipo de teoria correspondentista ingênua, que ignorasse completamente as limitações inerentes a todos os campos do conhecimento humano e que praticamente não encontraria defensores contemporâneos, poderia ser acusada de desconsiderar que o conhecimento sobre fatos pretéritos não é sempre possível e nunca será total. Qualquer concepção minimante crítica de verdade como correspondência já superou tais pretensões absolutas.

De todo o modo, as críticas céticas, ao desnudarem os problemas existentes em concepções ingênuas de realidade e conhecimento objetivo, pelas quais a verdade seria uma correspondência exata (ou cópia) do mundo real e estaria diretamente disponível à nossa cognição, contribuíram para o desenvolvimento de teorias mais críticas. Estas teorias, sem abandonar o referencial da relação com o mundo real, incorporaram uma preocupação com a carga conceptual-subjetiva que está presente em nossa forma de descrever o mundo e assimilaram que a verdade sobre fatos é sempre uma aproximação

\footnotetext{
${ }^{46}$ Como esclarece FERRER BELTRÁN (2007, p. 30), em um sistema de atribuição aleatória de sanções, "não havendo vinculação alguma entre cada um dos membros dessa sociedade e a probabilidade de ser sancionado, não há tampouco razão alguma para comportar-se de acordo com o estabelecido pelas normas jurídicas", de forma que "somente se o processo judicial cumpre a função de determinar a verdade das proposições referentes aos fatos o direito terá êxito como mecanismo pensado para dirigir a conduta dos seus destinatários".

${ }^{47}$ MACCORMICK, Neil. Retórica e o Estado de Direito. Trad. Conrado Hübner Mendes. Rio de Janeiro: Elsevier, 2008, p. 296.
} 
Revista Eletrônica de Direito Processual - REDP.

Rio de Janeiro. Ano 13. Volume 20. Número 1. Janeiro a Abril de 2019

Periódico Quadrimestral da Pós-Graduação Stricto Sensu em Direito Processual da UERJ

Patrono: José Carlos Barbosa Moreira (in mem.). ISSN 1982-7636. pp. 407-441

www.redp.uerj.br

probalística, limitada e não absoluta. Esta forma de pensar se apresenta como um cognoscitivismo orientado por um objetivismo. ${ }^{48}$

Por objetivismo crítico compreende-se, assim, uma postura epistemológica que concebe os enunciados fáticos como descrições de fatos que possuem existência independente desses enunciados, de forma que quem formula um enunciado fático pretende referir-se a uma realidade externa. ${ }^{49}$ Todavia, a despeito da existência independente desta realidade, o objetivismo crítico é consciente de que a reconstrução discursiva dos fatos é uma tarefa sujeita a diversas dificuldades, razão pela qual devem se submeter os elementos probatórios a uma análise criteriosa para identificar em que extensão eles são realistas e em que medida são construções do observador, além de se desenvolver mecanismos para identificar em que casos é possível, e com que grau de certeza, conhecer os fatos com objetividade. ${ }^{50}$

Portanto, o que se propõe é um conceito de verdade como correspondência que assume a existência do mundo real objetivo (realista), admite a possibilidade de se estabelecer uma relação entre as proposições acerca dos fatos e os fatos que ocorreram neste mundo empírico (cognoscitivismo), porém aceita que esta relação é intermediada pela linguagem, permeada pela subjetividade dos observadores e, ante estas dificuldades inafastáveis em absoluto, possui limitado grau de certeza (objetivismo crítico).

Nos termos desta formulação, a relação da teoria da verdade como correspondência assim delimitada com as teorias sintáticas e pragmáticas não é obrigatoriamente de rivalidade. Isso ocorre porque, enquanto a teoria correspondentista enfrenta de maneira ontológica o problema da verdade, as demais abordam a questão com maior ênfase nos meios que podem ser empregados para encontrá-la.

As concepções sintáticas, por exemplo, fundamentadas sobre o critério da coerência, compreendem que a verdade é a concordância de diversos enunciados fáticos entre si. De fato, esta perspectiva oferece um excelente critério para aferição da verdade, pois relatos incoerentes denunciam a existência de conteúdo inverídico. Todavia, a coerência não é condição suficiente para a verdade, ainda que possa ser necessária, pois verdadeiro é somente o enunciado que se adequa a realidade. ${ }^{51}$

\footnotetext{
${ }^{48}$ GONZALÉZ LAGIER, 2003, p. 22.

${ }^{49}$ GASCÓN ABELLÁN, 2010, p. 60.

${ }^{50}$ GONZALÉZ LAGIER, op. cit., p. 22.

${ }^{51}$ TARUFFO, 2008, p. 29
} 
Revista Eletrônica de Direito Processual - REDP.

Rio de Janeiro. Ano 13. Volume 20. Número 1. Janeiro a Abril de 2019

Periódico Quadrimestral da Pós-Graduação Stricto Sensu em Direito Processual da UERJ

Patrono: José Carlos Barbosa Moreira (in mem.). ISSN 1982-7636. pp. 407-441

www.redp.uerj.br

Admitir a conclusão contrária, assumindo a coerência como critério suficiente para definir a verdade causaria uma séria distorção prática. De fato, o critério da coerência, por si só, não assegura univocidade, pois um conjunto de elementos pode ser organizado em relatos diferentes e igualmente coerentes. Contudo, o fato de serem igualmente coerentes não significa que sejam igualmente aceitáveis como realidade ou que apresentem o mesmo grau de certeza. Considerando apenas o critério da coerência, as maiores extravagâncias, como contos de fadas, deveriam ser aceitas como verdadeiras, desde que o relato imaginário não contenha contradições. ${ }^{52}$

Contudo, uma perspectiva menos idealizada da coerência, que leve em consideração a necessidade de correspondência com o mundo real, supera esta barreira conceitual e alcança utilidade prática para o direito, como se pode observar na noção de coerência narrativa desenvolvida por MacCormick.

A proposta de MacCormick atribui centralidade a ideia de coerência, compreendendo que a descrição de um evento ou de um conjunto de eventos somente é digna de crédito se for coerente, o que implica a inexistência de inconsistência lógicas entre seus elementos factuais e a existência de uma explicação causal ou motivacional satisfatória para todo o complexo de eventos formulado. ${ }^{53}$ Todavia, o autor admite que narrativas não-ficcionais, como as que interessam ao direito, devem estar de algum modo "ancoradas" na realidade ${ }^{54}$, harmonizando a ideia de coerência com a de correspondência com o mundo real através de uma útil e necessária complementariedade.

Por outra parte, as diversas teorias pragmáticas ${ }^{55}$, para as quais a verdade é definida por sua aceitabilidade justificada ante determinados fins ou pelo consenso que proporciona, encontram-se mais distantes de uma correspondência com a realidade, porque promovem uma assimilação entre a verdade e os motivos que temos para aceitar que determinado enunciado fático é verdadeiro. ${ }^{56}$

Nestas teorias, a apresentação de uma justificação suficientemente racional para aceitarmos determinada proposição, consideradas condições epistêmicas ideais em

${ }^{52}$ GASCÓN ABELLÁN, 2010, p. 53

${ }^{53}$ MACCORMICK, 2008, p. 295.

${ }^{54}$ Ibidem, p. 296.

${ }^{55}$ Como em toda a classificação, sob o título de teorias pragmatistas são agrupados autores que possuem traços bastante distintos, cabendo aqui anotar "principalmente [as teorias elaboradas] por PIERCE, JAMES e DEWEY" e "as concepções de verdade de KUHN, HABERMAS ou PUTNAM" (GASCÓN ABELLÁN, 2010, p. 55).

${ }^{56}$ GASCÓN ABELLÁN, op. cit., p. 53 
Revista Eletrônica de Direito Processual - REDP.

Rio de Janeiro. Ano 13. Volume 20. Número 1. Janeiro a Abril de 2019

Periódico Quadrimestral da Pós-Graduação Stricto Sensu em Direito Processual da UERJ

Patrono: José Carlos Barbosa Moreira (in mem.). ISSN 1982-7636. pp. 407-441

www.redp.uerj.br

algumas formulações ${ }^{57}$, é suficiente para que esta proposição seja verdadeira. Este tipo de definição da verdade não se atenta à possibilidade de que eventualmente podemos ter as melhores razões para crermos que um enunciado é verdadeiro e, não obstante, resulte que o enunciado fático resulte desmentido quando confrontado com o mundo real. ${ }^{58} 59$

Desse modo, é preciso distinguir entre o que é aceitável pragmaticamente e o que é verdadeiro. A existência, nas discussões fáticas, de um referente empírico pré-existente é um dado inafastável, de forma que, considerada esta premissa, nenhuma maioria, nem mesmo a unanimidade dos consensos ou dissensos, pode tornar verdadeiro aquilo que é falso ou tornar falso o que é verdadeiro. ${ }^{60}$

Contudo, é necessário consignar que tanto o aceitável como o verdadeiro são utilizados na prática jurídica. Retomando a pergunta que iniciou a segunda parte deste estudo, podemos afirmar que, com seu raciocínio probatório, o juiz tem como principal objetivo justificar como concluiu que determinados fatos são verdadeiros, ou seja, como concluiu que determinados fatos efetivamente ocorreram no mundo de um determinado modo. Contudo, a afirmação de que a verdade é o principal objetivo da atividade jurisdicional não significa dizer que inexistam outras finalidades. ${ }^{61}$

Em muitos casos, especialmente em processos não penais, o sistema jurídico consente que aquilo acerca do que as partes concordam seja considerado verdadeiro, ou que determinados fatos não precisam ser provados. Trata-se, nestes casos, de escolhas contra-epistemológicas adotadas em favor de outras finalidades que também são relevantes para o direito. Um acordo entre as partes sobre determinada proposição não é capaz de dizer nada acerca da veracidade desta proposição, mas sua aceitação resulta útil para que se alcance uma economia processual, por exemplo. ${ }^{62}$

\footnotetext{
${ }^{57}$ HABERMAS, Jürgen. Teoria de la acción comunicativa: complementos y estudios previos. Tradução de Jiménez Redondo. Madrid: Cátedra, 1989.

${ }^{58}$ GASCÓN ABELLÁN, 2010, p. 57.

${ }^{59} \mathrm{Na}$ obra cinematográfica A vida de David Galle (2003), o personagem principal, militante contrário a pena de morte nos Estados Unidos da América, conscientemente cria uma situação na qual todas as razões solidamente justificam que ele seja julgado culpado por homicídio, o que, de fato, conduz à sua execução pela prática do referido delito. Todavia, a sua culpa revela-se, por fim, uma asserção falsa. $\mathrm{O}$ drama cinematográfico ilustra artisticamente as dificuldades de se aceitar a existência de justificativas aceitáveis como critério último de verdade.

${ }^{60}$ TARUFFO, 2013, p. 244.

${ }^{61}$ FERRER BELTRÁN, Jordi. La valoración racional de la prueba. Madrid: Marcial Pons, 2007, p. 31.

${ }^{62}$ TARUFFO, op. cit., p. 244.
} 
Revista Eletrônica de Direito Processual - REDP.

Rio de Janeiro. Ano 13. Volume 20. Número 1. Janeiro a Abril de 2019

Periódico Quadrimestral da Pós-Graduação Stricto Sensu em Direito Processual da UERJ

Patrono: José Carlos Barbosa Moreira (in mem.). ISSN 1982-7636. pp. 407-441

www.redp.uerj.br

Um dos melhores exemplos da pontual renúncia à pretensão epistemológica do processo judicial é o caso das provas ilícitas. Embora a prova ilícita pudesse ser, para a busca da verdade, um elemento essencial, sua admissão constituiria justamente a negação daquilo que o processo pretende assegurar: a vigência do direito. A prova ilícita é, assim, uma crise no modo de funcionamento regular do processo, que se soluciona em favor da legalidade, sem a qual o próprio processo não teria sentido. Do mesmo modo, várias outras limitações de caráter não epistemológico são impostas por regras de direito processual e probatório, as quais se encarregam de compatibilizar a pretensão epistemológica fundamental do processo com outras finalidades perseguidas pelo direito, como a celeridade processual, o contraditório, a dignidade e etc.

Neste contexto, embora uma teoria pragmática da verdade desempenhe um papel muito limitado enquanto a pretensão epistemológica do processo estiver sendo privilegiada, vários fatores podem (e muitas vezes devem) fazer com que a busca pela verdade seja colocada em segundo plano na atividade processual. A partir da adoção desta orientação não epistemológica, as teorias pragmáticas da verdade são úteis para explicar a construção de acordos e presunções. ${ }^{63}$

Portanto, em termos gerais, especialmente no âmbito penal, a atividade justificativa fático-probatória se orienta ordinariamente por um comando epistemológico, em busca da verdade acerca de como os fatos ocorreram no mundo, que é o que juiz pretende demonstrar em suas decisões. Contudo, esta orientação à verdade pode ser legitimamente afastada em determinados momentos pelo ordenamento jurídico em favor de outras finalidades também perseguidas pelo sistema judicial. ${ }^{64}$

\section{Processo e decisão acerca dos fatos nos processos penais sob o enfoque argumentativo-constitucional}

É possível compreender a atividade do juiz no processo penal a partir do duplo aspecto que antes se assinalava: de um lado a busca da verdade e de outro a observância a

\footnotetext{
${ }^{63}$ TARUFFO, 2013, p. 244.

${ }^{64}$ Deve-se salientar que algumas renúncias epistemológicas se encontram plenamente justificadas, como a absolvição por ausência de provas e a proibição de provas ilícitas. Todavia, especialmente no que tange aos chamados mecanismos "consensuais" para a aplicação de sanções penais, que transacionam no âmbito do direito indisponível à liberdade e em contextos de evidente disparidade de poderes entre defesa e acusação, o afastamento da busca pela verdade jurídica através do processo em favor da verdade "pactuada" entre as partes é alvo de severas críticas. Ver.: TARUFFO, 2014.
} 
Revista Eletrônica de Direito Processual - REDP.

Rio de Janeiro. Ano 13. Volume 20. Número 1. Janeiro a Abril de 2019

Periódico Quadrimestral da Pós-Graduação Stricto Sensu em Direito Processual da UERJ

Patrono: José Carlos Barbosa Moreira (in mem.). ISSN 1982-7636. pp. 407-441

www.redp.uerj.br

outras finalidades importantes para o direito. Também já foi assinalado que esta atividade é especialmente mais complexa no contexto de Estados constitucionais, nos quais a argumentação nos raciocínios probatórios é fundamental. A partir destas premissas, o que se pode depreender acerca do processo e da decisão judicial sobre fatos?

Uma conclusão que pode ser extraída da atividade jurisdicional penal entendida nestes termos consiste em levar a sério o processo como atividade epistemológica, no sentido de que é somente através do processo que se pode alcançar algum conhecimento acerca dos fatos. Para que isto seja possível, o juiz deve assumir conscientemente a posição inicial de quem desconhece a verdade sobre os fatos em discussão. Esta postura inicial sem pré-julgamentos acerca do fato particular submetido à cognição processual exige do juiz independência e imparcialidade.

A independência não consiste apenas, como se costuma sintetizar, na ausência de interferência dos demais poderes do Estado na atividade jurisdicional. Para o juiz de um estado constitucional, a independência consiste na ausência de submissão a qualquer outro interesse que não seja a concretização do direito. Na condução do processo e na valoração probatória, o juiz deve agir tendo em vista a posição institucional que ocupa, afastando-se tanto da interferência de fatores externos ao processo (imprensa, grupos políticos, repercussão social...) quanto de suas próprias crenças e preferências pessoais que, embora legitimamente assumidas em sua autonomia privada, não se coadunem com o exercício da sua função pública que desempenha. De fato, o poder jurisdicional não é um poder atribuído ao juiz para sua realização pessoal, mas para a realização da ordem jurídica, única a qual ele deve estar submetido. ${ }^{65}$

A imparcialidade, por seu turno, refere-se à independência do juiz frente a fatores internos ao processo, é dizer, às partes e ao objeto em discussão. ${ }^{66}$ Uma vez que o único interesse ao qual o juiz se submete é a concretização do direito, compete-lhe dirigir a atividade processual à esta finalidade. No curso do processo, é seu dever a equidistância, garantindo que haja entre as partes igualdade de participação e oportunidades probatórias. Quando alcançado o momento da decisão, o juiz deve estar comprometido apenas com a verdade dos fatos que considere poder justificar de maneira satisfatória, a despeito dos

\footnotetext{
${ }^{65}$ AGUILÓ REGLA, 2003, p. 48/50.

${ }^{66}$ Ibidem, p. 55.
} 
Revista Eletrônica de Direito Processual - REDP.

Rio de Janeiro. Ano 13. Volume 20. Número 1. Janeiro a Abril de 2019

Periódico Quadrimestral da Pós-Graduação Stricto Sensu em Direito Processual da UERJ

Patrono: José Carlos Barbosa Moreira (in mem.). ISSN 1982-7636. pp. 407-441

www.redp.uerj.br

prejuízos ou vantagens que eles possam implicar para as partes e da repercussão que possa ter o objeto do processo.

Uma outra conclusão que se extrai das premissas da atividade jurisdicional em um contexto constitucional-argumentativo diz respeito à relevância da participação das partes. O conhecimento dos fatos pela via processual, entendida como atividade precipuamente epistemológica, não é perseguido de forma direta e imediata pelo juiz, mas somente por intermédio da dialética argumentativa que se constrói em torno das teses contrapostas pelas partes em litígio. Desse modo, a discussão sobre os fatos somente tem sentido quando entra em contato com as posições jurídicas concretamente sustentadas pelos litigantes, o que torna imprescindível a intervenção substantiva das partes desde o momento da fixação dos fatos a serem provados, passando pela atividade de escolha e produção do material probatório relevante e chegando à análise final de qual interpretação deve ser dada ao conjunto probatório produzido. ${ }^{67}$

Para que esta participação das partes no processo seja efetiva, é indispensável que esteja garantido o exercício do contraditório entre elas em igualdade de condições, exigência que se justifica tanto jurídica como epistemologicamente. Do ponto de vista epistemológico, o método dialético assumido pelo processo assegura melhores condições para a obtenção da verdade, permitindo que cada parte apresente à parte contrária e ao juiz o conjunto de dados e argumentos probatórios considerados mais idôneos para defender sua tese fática, em interlocução com os elementos análogos aportados pelos demais sujeitos do processo. ${ }^{68}$ Do ponto de vista jurídico, o devido processo legal, que supõe o direito a um contraditório efetivo e à paridade de armas, é uma das aspirações mais fundamentais dos Estados constitucionais, pois se vincula diretamente ao objetivo de erradicação da arbitrariedade. ${ }^{69}$

Igualmente decorre de uma compreensão constitucional-argumentativa da atividade jurisdicional penal o elevado grau de qualidade exigível da justificação do raciocínio fático-probatório adotado nas decisões judiciais. Esta justificação não pode se limitar a uma simples descrição do itinerário decisional mental do juiz nem pode ser confundida com a mera exteriorização do produto da livre valoração interna do julgador, hipóteses que

${ }^{67}$ UBERTIS, Giulio. Elementos de epistemología del processo judicial. Tradução de Perfecto Andrés Ibáñez. Madrid: Trotta, 2017, p. 53/55.

${ }^{68}$ UBERTIS, op. cit, p. 58.

${ }^{69}$ Cf. AGUILÓ REGLA, 2001. 
Revista Eletrônica de Direito Processual - REDP.

Rio de Janeiro. Ano 13. Volume 20. Número 1. Janeiro a Abril de 2019

Periódico Quadrimestral da Pós-Graduação Stricto Sensu em Direito Processual da UERJ

Patrono: José Carlos Barbosa Moreira (in mem.). ISSN 1982-7636. pp. 407-441

www.redp.uerj.br

estariam mais próximas do contexto da descoberta e, por isso, estariam adstritas a certo psicologismo. Pelo contrário, a motivação da decisão acerca dos fatos demanda a apresentação das razões pelas quais determinadas provas foram consideradas na sentença e outras desconsideradas, a indicação dos pesos atribuídos aos elementos probatórios e os fundamentos desta valoração, as inferências realizadas a partir das provas e os parâmetros empregados para aferir o grau de certeza do raciocínio probatório.

Esta exigência de justificação precisa e completa desempenha um papel crítico no controle discursivo em dois momentos distintos. Em primeiro lugar, quando torna obrigatório o exercício de uma autocrítica pelo juiz ao externalizar discursivamente seu raciocínio probatório, comprometendo-o com as razões que expõe, o que reduz os riscos de uma assimilação irrefletida de sugestões subjetivas insuscetíveis de defesa racional. ${ }^{70} \mathrm{Em}$ segundo lugar, porque autoriza uma revisão mais ampla do raciocínio probatório pelos órgãos judiciais recursais, permitindo que as partes possam apresentar recursos circunscritos especificamente aos pontos que considerem equivocados e facilitando o juízo avaliativo próprio destes órgãos de revisão, aos quais compete verificar se o juízo sentenciante conseguiu fazer com que os fatos assumidos como provados fossem efetivamente comunicados de forma compreensível e se os critérios de correção fática adotados são capazes de sustentar as conclusões alcançadas. ${ }^{71}$

Por fim, um processo judicial com ambição cognoscitiva, nos termos dos pressupostos assumidos até aqui, condensa em si uma dupla pretensão (verdade e direito), mas igualmente é constrangida por uma dupla limitação.

A busca da verdade no contexto judicial, como em qualquer outro contexto de investigação, está sujeita às limitações do conhecimento humano, que é necessariamente condicionado aos dados e tecnologias disponíveis. Se nem mesmo nas chamadas ciências duras a ideia de uma verdade absoluta persiste, não há qualquer razão para que se exija das decisões judiciais o cumprimento deste pressuposto inalcançável. Em realidade, não se deve confundir a verdade tomada como ideal regulativo e a verdade que o processo efetivamente consegue produzir. Esta é sempre uma aproximação com maior ou menor grau de certeza probabilística em relação àquela. ${ }^{72}$

\footnotetext{
70 ANDRÉS IBAÑEZ, 1992, p. 292.

${ }^{71}$ UBERTIS, 2017, p. 68.

72 TARUFFO, 2008, p. 26.
} 
Revista Eletrônica de Direito Processual - REDP.

Rio de Janeiro. Ano 13. Volume 20. Número 1. Janeiro a Abril de 2019

Periódico Quadrimestral da Pós-Graduação Stricto Sensu em Direito Processual da UERJ

Patrono: José Carlos Barbosa Moreira (in mem.). ISSN 1982-7636. pp. 407-441

www.redp.uerj.br

Isso porque, de um lado, a estrutura predominantemente indutiva do raciocínio probatório torna inviável, independente de quão grande ou relevante seja o conjunto probatório disponível, que se obtenha uma certeza lógica a partir da valoração das provas no processo judicial. Apesar de alguma possível exceção na qual um argumento sobre fatos tenha caráter dedutivo ${ }^{73}$, este tipo de argumento em regra está estruturado de maneira indutiva (ou abdutiva), exatamente para que se consiga, com amparo nas informações que se possui e em algumas regras de regularidade generalizadas (ou máximas de experiência), alcançar uma conclusão que está além das premissas, o que necessariamente se converte em um juízo probalístico.

Pode-se tomar como exemplo um determinando processo no qual a testemunha $\mathrm{X}$ afirma que viu o acusado $\mathrm{Y}$ furtar um objeto $\mathrm{Z}$. A única coisa que se pode depreender diretamente desta informação é que a testemunha $X$ formulou estas afirmações, mas não que as afirmações formuladas são verdadeiras. Para que este último seja considerado provado seria necessário assumir que a testemunha não mente, não sofreu nenhum problema de percepção, não teve sua memória afetada e etc. A assunção destas circunstâncias se apoia em leis de natureza probabilística (que normalmente testemunhas nestas condições não mentem, que normalmente testemunhas nestas condições não sofrem problemas de percepção, que normalmente testemunhas nestas condições não tem sua memória afetada e etc). Assim, o raciocínio indutivo transmite naturalmente o seu grau de incerteza para a conclusão probatória, o que é uma limitação inafastável, embora possa ser reduzida pela maior ou menor certeza probalística que as premissas utilizadas nos raciocínios possam oferecer. ${ }^{74}$

De outro lado, além da limitação lógica, é necessário assinalar as várias outras dificuldades que podem ser encontradas na apuração judicial dos fatos. O desaparecimento de vestígios, a impossibilidade de identificação dos participantes dos fatos, as dificuldades tecnológicas e vários outros fatores influem diretamente no processo judicial, limitando de forma concreta a pretensão probatória. Desse modo, seja por razões lógicas ou factuais, a

\footnotetext{
${ }^{73}$ GONZALÉZ LAGIER (2003) sustenta que um mesmo argumento fático-probatório pode ser apresentando tanto de maneira indutiva, como de maneira abdutiva ou dedutiva. Em todos os casos, o raciocínio permanece sendo probabilístico, pois, mesmo quando apresentado de forma dedutiva, haverá sempre uma incerteza acerca das premissas do silogismo, a qual será transferida para conclusão.

${ }^{74}$ GASCÓN ABELLÁN, 2010, p. 92/93.
} 
Revista Eletrônica de Direito Processual - REDP.

Rio de Janeiro. Ano 13. Volume 20. Número 1. Janeiro a Abril de 2019

Periódico Quadrimestral da Pós-Graduação Stricto Sensu em Direito Processual da UERJ

Patrono: José Carlos Barbosa Moreira (in mem.). ISSN 1982-7636. pp. 407-441

www.redp.uerj.br

pretensão epistemológica do processo somente pode ser parcialmente atendida, sempre remanescendo algum âmbito de incerteza.

No entanto, ainda que todas as condições factuais necessárias estivessem satisfeitas e fosse possível atribuir, de alguma maneira, certeza absoluta às induções probatórias, a eliminação dos obstáculos epistemológicos não seria suficiente para garantir o livre acesso à verdade no processo, em razão das limitações jurídicas aos quais também se submete a cognição judicial dos fatos.

A verdade que se pode alcançar no processo fica condicionada pela incidência de normas jurídicas que estabelecem diversos limites acerca do tempo, dos meios e dos procedimentos que podem ser utilizados pelos juízes e pelas partes. A existência destas regras e princípios jurídico-processuais não constituem necessariamente um obstáculo à busca da verdade, embora muitas vezes o seja. ${ }^{75}$

Algumas normas jurídicas reforçam o objetivo de averiguação da verdade, exercendo, ao mesmo tempo, uma função epistemológica e institucional. Nessa classe estão, por exemplo, as regras que proíbem aquisição de testemunhos mediante tortura, a qual se justifica não apenas em razão do valor fundamental da vida e da dignidade humana, mas também porque informações obtidas por esta via geralmente se apresentam distorcidas e carregam uma debilidade epistemológica, pois o evidente estresse psicológico prejudica a memória e favorece o sugestionamento. ${ }^{76}$

Por outro lado, há normas jurídicas de cunho não-epistemológico que se convertem em verdadeiros comandos contra-epistemológicos. Nessa classe estaria, por exemplo, a limitação temporal imposta pela exigência de razoável duração do processo. Deste princípio jurídico decorrem regras acerca dos prazos para a prática de atos probatórios, interposição de recursos e formação decisão definitiva (coisa julgada). A permissão para que o processo se prolongasse em busca da verdade por tempo indeterminado implicaria inadmissível situação de incerteza para o investigado e indevida leniência com o Estado que tem o dever de prestar jurisdição de forma eficiente. ${ }^{77}$ Desse modo, diante da necessidade de prestação jurisdicional em tempo razoável, a demora excessiva pode impor

\footnotetext{
75 TARUFFO, 2008, p. 25.

${ }^{76}$ GASCÓN ABELLÁN, 2010, p. 118.

${ }^{77}$ FERRER BELTRÁN, 2007, p. 37.
} 
Revista Eletrônica de Direito Processual - REDP.

Rio de Janeiro. Ano 13. Volume 20. Número 1. Janeiro a Abril de 2019

Periódico Quadrimestral da Pós-Graduação Stricto Sensu em Direito Processual da UERJ

Patrono: José Carlos Barbosa Moreira (in mem.). ISSN 1982-7636. pp. 407-441

www.redp.uerj.br

um abandono da busca pela verdade no processo, normalmente com a resolução de questões pendentes por presunções. ${ }^{78}$

A observância dos limites jurídicos impostos pelas normas que regulam o processo é importante para salvaguardar a coerência do direito, que não pode negar a si mesmo a fim de satisfazer a pretensão epistemológica. Todavia, há situações em que as normas jurídicas, especialmente os princípios, estarão sobrepostos e tornarão menos claros os limites a serem observados na atividade probatória.

É possível pensar em uma situação na qual haja um quadro fático-probatório suficientemente seguro para condenação penal, porém exista uma única prova, obtida de forma ilícita pela defesa, suficiente e necessária para comprovar a inocência do acusado. Nesta situação, uma ponderação entre o princípio do devido processo legal (que subjaz à proibição do uso de provas ilícitas) e o princípio da dignidade humana (que se opõe a condenação de um inocente) seria necessária, havendo normalmente a prevalência do segundo sobre o primeiro. ${ }^{79}$ Em todo caso, o que se deve realçar é que, em casos difíceis como este, a solução não está em abandonar os limites do direito, mas em delinear de forma mais clara seu perímetro, ao qual a atividade processual sempre deverá estar circunscrita, sob pena de perder sua legitimidade constitucional.

Por tudo o que foi exposto, a atividade processual e decisória no processo penal, sob o marco argumentativo-constitucional que se sustenta neste estudo, deve levar em consideração cinco ideias fundamentais: 1) independência e imparcialidade do juiz; 2) participação das partes; 3) justificação do raciocínio probatório; 4) limitações epistemológicas; e 5) limitações jurídicas. Estes são pontos de partida e, portanto, não pretendem solucionar os variados problemas que emergem da prática do processo penal. Todavia, apresentam um arcabouço teórico razoavelmente preciso e claro, em torno do qual estes problemas podem ser articulados para melhor compreensão e discussão.

\section{Conclusão: argumentação e busca da verdade no processo penal.}

\footnotetext{
78 Entre as diversas presunções presentes no sistema jurídico, algumas possuem caráter mais formal e desconectado da realidade, desempenhando um papel predominantemente não epistemológico. Há, contudo, presunções que mais se assemelham a máximas de experiência institucionalizadas, as quais também contém um traço epistemológico em sua formulação. Para uma discussão sobre o assunto, ver: GASCÓN ABELLÁN, 2010, p. 123/135.

${ }^{79}$ PRADO, Leandro Cadenas. Prova ilícitas - teoria e interpretação dos tribunais superiores. $2^{\mathrm{a}}$ Ed. Rio de Janeiro: Impetus, 2009, p. 32.
} 
Revista Eletrônica de Direito Processual - REDP.

Rio de Janeiro. Ano 13. Volume 20. Número 1. Janeiro a Abril de 2019

Periódico Quadrimestral da Pós-Graduação Stricto Sensu em Direito Processual da UERJ

Patrono: José Carlos Barbosa Moreira (in mem.). ISSN 1982-7636. pp. 407-441

www.redp.uerj.br

Toda a explanação desenvolvida neste estudo está assentada na ideia de que, no contexto constitucional contemporâneo, a justificação das decisões judiciais é uma exigência fundamental para o exercício do poder jurisdicional que deve permear toda a atividade do juiz, inclusive nos aspectos probatórios. Especialmente no processo penal, a fundamentação de decisões condenatórias, nas quais os aspectos fáticos são cruciais, deve ser capaz de satisfazer a elevada carga argumentativa necessária para derrotar a presunção de não-culpabilidade. Portanto, o cumprimento adequado do dever de fundamentação das sentenças penais não pode ser reduzido a uma simples declaração das conclusões do julgador, mas exige a apresentação de um raciocínio substancial.

Em termos argumentativos, isto significa dizer que o dever de fundamentação do juiz não está adstrito a demonstração das relações lógicas entre as premissas fática/normativa do silogismo judicial e a conclusão do julgamento (justificação interna). Em verdade, o grande desafio da prestação jurisdicional nos Estados constitucionais consiste na demonstração da correção das premissas empregadas (justificação externa). Esta justificação mais exigente, no campo do raciocínio fático-probatório, demanda que estejam expressas no ato jurisdicional as provas utilizadas ou rejeitadas, o valor atribuído a cada uma delas, os critérios utilizados para a valoração probatória e as razões pelas quais se deve acreditar que a conclusão alcançada é a melhor reconstrução possível dos fatos, tendo como parâmetro a ideia de verdade como correspondência.

Com efeito, uma teoria semântica da verdade (verdade como correspondência com o mundo real) é fundamental para justificar a existência do processo judicial, inclusive porque sem ela o direito não poderia cumprir adequadamente a função de orientar as condutas humanas. Em verdade, caso se dispensasse a necessária vinculação entre os fatos que efetivamente ocorreram no mundo e as suas consequências jurídicas, haveria uma forte abertura à aleatoriedade, o que romperia com a ideia de que as sanções são aplicadas em razão de fatos e de que é possível evitá-las com comportamentos conforme o direito.

Todavia, a ideia de verdade como correspondência não exclui a utilidade de outras concepções epistemológicas no processo, especialmente as teorias sintáticas (verdade como coerência) e as teorias pragmáticas (verdade como consenso). A coerência constitui um excelente critério para aferição da verdade, embora não seja único nem suficiente para assegurá-la. Por outro lado, o consenso é especialmente relevante nos diversos institutos 
Revista Eletrônica de Direito Processual - REDP.

Rio de Janeiro. Ano 13. Volume 20. Número 1. Janeiro a Abril de 2019

Periódico Quadrimestral da Pós-Graduação Stricto Sensu em Direito Processual da UERJ

Patrono: José Carlos Barbosa Moreira (in mem.). ISSN 1982-7636. pp. 407-441

www.redp.uerj.br

jurídicos em que a pretensão epistemológica é mitigada em prol de outras finalidades também importantes para o direito, como a segurança jurídica e a economia processual.

De fato, o processo judicial, especialmente no âmbito penal, possui como objetivo alcançar a melhor verdade possível dentro dos limites institucionais do direito, ou seja, encontrar a proposição mais próxima da forma como os fatos efetivamente aconteceram no mundo real sem ultrapassar os limites normativos. Todavia, a conciliação entre verdade e direito através do processo é intrinsicamente conflitiva, de modo que, em muitos pontos, os limites deste último tornarão inviável a consecução da primeira. É possível depreender de uma concepção do processo assim delineada diversas implicações, as quais podem ser sintetizados em cinco pontos de partida fundamentais: a independência e imparcialidade do julgador; a participação efetiva das partes no processo; o elevado grau de qualidade exigível da justificação das conclusões fáticas; a consideração dos limites epistemológicos do conhecimento humano e; o respeito aos limites normativos na busca pela verdade no processo. Estes pontos, embora limitados, abarcam a maior parte dos problemas suscitados no campo processual penal atualmente.

\section{REFERÊNCIAS BIBLIOGRÁFICAS:}

ANDRÉS IBÁÑEZ, Perfecto. Acerca de la motivación de los hechos en la sentencia penal. DOXA, nº 12, p. 257-299, 1992.

AGUILÓ REGLA, Josep. De nuevo sobre independencia e imparcialidad de los jueces y argumentación jurídica. Jueces para la democracia, nº 46, p. 47-56, 2003.

. Sobre la constitución del Estado constitucional. DOXA, nº 24, p. 429-458, 2001.

ALEXY, Robert. Teoria de la argumentación jurídica. Tradução de Manuel Atienza e Isabel Espejo. 2. ed. Madrid: Centro de Estudios Políticos y Constitucionales, 2007.

ATIENZA, Manuel. Sobre la argumentación en materia de hechos: Comentario crítico a las tesis de Perfecto Andrés Ibáñez. DOXA, nº 22, p. 82-86, 1994.

. As razões do direito: teorias da argumentação jurídica. Tradução de Maria Cristina Guimarães Cupertino. $3^{\mathrm{a}}$ ed. São Paulo: Landy, 2003.

. Curso de argumentación jurídica. Madrid: Trotta, 2013.

. O direito como argumentação. Lisboa: Escolar Editora, 2014. 
Revista Eletrônica de Direito Processual - REDP.

Rio de Janeiro. Ano 13. Volume 20. Número 1. Janeiro a Abril de 2019

Periódico Quadrimestral da Pós-Graduação Stricto Sensu em Direito Processual da UERJ

Patrono: José Carlos Barbosa Moreira (in mem.). ISSN 1982-7636. pp. 407-441

www.redp.uerj.br

ATIENZA, Manuel. RUIZ MANERO, Juan. Las piezas del Derecho: Teoría de los enunciados jurídicos. Barcelona: Ariel, 1996.

. La dimensión institucional del derecho y la justificación jurídica. DOXA, nº 24, p.

115-130, 2001.

BRUM, Nilo Bairros de. Requisitos retóricos da sentença penal condenatória. São Paulo: Editora RT, 1980.

DWORKIN, Ronald. Taking Rights Seriously. Cambridge: Harvard, University Press, 1977.

FERRAJOLI, Luigi. El futuro de la filosofía del derecho. DOXA, no 39, p. pp. 255-263, 2016.

. Principia iuris: teoría del derecho y de la democracia. Tradução de Perfecto Andrés Ibáñez, Carlos Bayón, Marina Gascón, Luis Prieto Sanchís y Alfonso Ruiz Miguel. Madrid: Trotta, 2011.

FERRAZ JUNIOR, Tercio Sampaio. Introdução ao Estudo do direito: técnica, decisão, dominação. $5^{\text {a }}$ ed. São Paulo: Atlas, 2007.

FERRER BELTRÁN, Jordi. La valoración racional de la prueba. Madrid: Marcial Pons, 2007.

GASCÓN ABELLÁN, Marina. Los hechos en el derecho. Madrid: Marcial Pons Ediciones, 2010.

GEORGE, Robert Peter. Natural Law. The American Journal of Jurisprudence, $\mathrm{n}^{\circ} 52$, pp. 55-75, 2007.

GONZÁLEZ LAGIER, Daniel. Hechos y argumentos. Racionalidad epistemológica y prueba de los hechos en el proceso penal -I. Jueces para la democracia, $n^{\circ} 46$, p.1726. 2003.

HABERMAS, Jürgen. Teoria de la acción comunicativa: complementos y estudios previos. Tradução de Jiménez Redondo. Madrid: Cátedra, 1989.

HACK, Susan. Of Truth, in Science and in Law. Brooklyn Law Review, v. 73:3, p. 985$1008,2008$.

MACCORMICK, Neil. Retórica e o Estado de Direito. Trad. Conrado Hübner Mendes. Rio de Janeiro: Elsevier, 2008.

MAIER, Julio; STRUENSEE, Eberhard. Las Reformas Procesales Penales en América Latina. Buenos Aires: Ad-Hoc, 2000. 
Revista Eletrônica de Direito Processual - REDP.

Rio de Janeiro. Ano 13. Volume 20. Número 1. Janeiro a Abril de 2019

Periódico Quadrimestral da Pós-Graduação Stricto Sensu em Direito Processual da UERJ

Patrono: José Carlos Barbosa Moreira (in mem.). ISSN 1982-7636. pp. 407-441

www.redp.uerj.br

MARTÍNEZ-FREIRE, Pascual F. La teoría de la verdade de Alfred Tarski. Contrastes.

Revista Internacional de Filosofía, p. 99-111, 2016.

MELÉNDEZ, Raul. La noción de verdade como correspondência. Ideas y Valores, n. 120, p. 121-128, 2002.

MORESO, José Juan. El positivismo jurídico y la aplicación del Derecho. DOXA, nº 27, p. 45-62, 2004.

PRADO, Leandro Cadenas. Prova ilícitas - teoria e interpretação dos tribunais superiores. $2^{\text {a }}$ Ed. Rio de Janeiro: Impetus, 2009.

RÓDENAS CALATAYUD, Ángeles. ¿Qué queda del positivismo jurídico? DOXA, nº 26, p. 417-448, 2003.

ROESLER, Cláudia. O papel de Theodor Viehweg na fundação das teorias da argumentação jurídica. Revista Eletrônica Direito e Política, v. 4, n. 3, p. 36-54, 2009.

ROSS, Alf. Sobre el derecho y la justicia. 2. ed. Buenos Aires: Eudeba, 1997.

SCHÖNBOHM, Hosrt. Manual de Sentencias Penales: aspectos generales de estructura, argumentación y valoración probatoria. Lima: ARA Editores, 2014.

TARUFFO, Michele. La prueba. Tradução de Laura Manríquez e Jordi Ferrer Beltrán. Madrid: Marcial Pons, 2008.

. La Verdad en el Proceso. Derecho \& Sociedad, n. 40, p. 239-248, 2013.

. Verdade negociada? Revista Eletrônica de Direito Processual, v. 13, n. 13, p. 634-657, 2014.

TOULMIN, Stephen. The uses of argument. Cambridge: Cambridge University Press, 1958.

UBERTIS, Giulio. Elementos de epistemología del processo judicial. Tradução de Perfecto Andrés Ibáñez. Madrid: Trotta, 2017. 